\title{
Kroppsøvingsfaget i bevegelse
}

\author{
Kjersti Mordal Moen ${ }^{1 \star}$ og Øyvind F. Standal ${ }^{2}$ \\ ${ }^{1}$ Høgskolen $\mathrm{i}$ Innlandet og ${ }^{2} \mathrm{OsloMet}$
}

I forkant av kroppsøvingskonferansen ved Norges idrettshøgskole juni 2018, ble undertegnede forspurt av daværende redaktør i JASEd, professor Anna-Lena Østern, om å være gjesteredaktører for et nytt temanummer innen kroppsøving og idrettsfag. Før konferansen gikk av stabelen, ble det sendt ut invitasjon til deltagerne om å bidra med artikler til temanummeret Kroppsøvingsfaget $i$ bevegelse. Deadline for innsending ble satt til 01.11.2018. Som i det forrige temanummeret fra 2017, omhandler også dette temanummeret forskning på skolefagene kroppsøving og idrettsfag, samt kroppsøvingslærerutdanning.

Temanummeret inneholder fem artikler. Samlet sett dekker disse artiklene flere av områdene som det kroppsøvingsfaglige miljøet i Norge er opptatt av: Kroppsøvingslærerutdanning, læreplanutvikling og helse, samt hvordan alle elever kan ha gode opplevelser i faget. I den første artikkelen er det helse i kroppsøving som blir satt på dagsorden. Dette er en relevant tematikk da vi vet at skolen og kroppsøvingsfaget av mange blir pekt på som en arena som bør ta større ansvar for barn og unges helse. Hanne H. Mong har bidratt med artikkelen "I kroppsøving så tenker jeg nok mest på det fysiske' - En studie om kroppsøvingslæreres forståelse av helse». Artikkelen retter søkelys på hvordan kroppsøvingslærere forstår og underviser om helse på ungdomstrinnet. Gjennom å intervjue åtte kroppsøvingslærere finner Mong at lærerne bygger sin undervisning om helse på egne helseforståelser, snarere enn teoretiske og sammensatte helseforståelser. Hun finner også at undervisningen om helse i liten grad bygger på systematisk planleggingsarbeid fra lærerens side. Studien til Mong er viktig både fordi det er en av få norske studier om helse i kroppsøving, men ikke minst fordi den bidrar med empirisk kunnskap om læreres helseforståelse og undervisningspraksis. Funn fra Mong sin studie bør bidra til debatt både blant kroppsøvingslærere og 


\section{K. M. Moen og Ø. F. Standal}

i kroppsøvingslærerutdanning. De problemstillinger som reises og funn fra studien er også svært relevante inn i den offentlige debatten om helse i kroppsøvingsfaget. ${ }^{1}$

Trine Ørbcek og Gunn Engelsrud har skrevet artikkelen «Sårbarhet som profesjonsetisk kompetanse? En metarefleksjon basert på undervising i skapende dans i høyere utdanning». I en nyskapende innramming stiller de i artikkelen spørsmål om erfaringer av sårbarhet kan gis relevans i relasjon til profesjonsetisk kompetanse i lærerutdanning. Ut fra et case med undervisning om skapende dans i kroppsøvingslærerutdanning giør forfatterne en analyse av en lærerutdanners metarefleksjon over denne undervisningen. Ved å bruke etiske og fenomenologiske begreper analyserer Ørbæk og Engelsrud seg frem til at det kan være relevant å diskutere sårbarhet som profesjonsetisk kompetanse, særlig knyttet til etiske og moralske handlingsvalg i undervisningsøyeblikk som ofte krever umiddelbar handling fra lærerens side. Selv om artikkelen bruker dans som case er det diskusjon av etiske, moralske og refleksive handlingsvalg som står sentralt, noe som gir artikkelen relevans for lærerutdanning og undervisning generelt.

Hilde Rustad og Tonje Fjogstad Langnes har brukt egen undervisningsarena som forskningsfelt når de har ønsket å forstå lærerstudenter og deres erfaringer knyttet til gjennomføring av flashmob som studentdrevet danseprosjekt. Kritikken av teoripraksisgapet innen lærerutdanning har vært mye uttalt. Funn i artikkelen «Flashmob i lærerutdanninger - studenters erfaringer med å skape dans sammen", viser at det ligger et stort potensiale og mange mulighetsrom i kroppsøvingslærerutdanningen for å skape sammenhenger mellom teori og praksis for studentene. Gjennom tekster der studentene skriver om sine erfaringer fra danseprosjektet finner forfatterne at følgende fire temaer står sentralt: 'følelser', 'å skape dans', 'nærhet og samarbeid' og 'lærerrollen'. Artikkelforfatterne diskuterer at disse temaene viser at flashmobprosjektet har relevans i et lærerutdanningsperspektiv ved at studenterfaringene kan knyttes til selvbestemmelse, medbestemmelse og solidaritet. Det framkommer tydelige sammenhenger mellom studentenes erfaringer og profesjonspersonlig kompetanse.

Fagfornyelsen som for tiden foregår i norsk skole vil føre frem til ny læreplan i kroppsøving. Idar Lyngstad analyserer i artikkelen «Motstridende mål i kroppsøving i Norge - en analyse av læreplanene i faget i perioden 2006 til 2015» nylige endringer gjort i læreplanen for kroppsøving. Analysene er gjort i lys av arbeidene til P. J. Arnold og Claes Annerstedt. Lyngstad viser at det finnes en spenning i læreplanen mellom på den ene side idrettslige og såkalte fysisk-motoriske ferdigheter som har forhåndsdefinerte kriterier for måloppnåelse, og på den andre side mål for ferdighetsutvikling som er mer åpne for tilpasninger til forskjellige elevforutsetninger. Artikkelen er dermed svært tidsaktuell og inviterer til refleksjon over hvilke endringer den nye læreplanen kan føre til.

Irina B. Erdvik,Tommy Haugen, Andreas Ivarsson og Reidar Säfvenbom presenterer i sin artikkel, «Development of basic psychological need satisfaction in physical education:

\footnotetext{
${ }^{1}$ Øyvind Førland Standal er hovedveileder for Hanne H. Mong. For ordens skyld skal det understrekes at Standal ikke har deltatt i vurderingen av artikkelen.
} 
Effects of a two-year PE programme", en intervensjon-studie med interessebasert kroppsøving. Interessebasert kroppsøving var et tilbud som gikk over 2 år, der elever kunne velge mellom det forfatterne kaller en utforskende tilnærming til kroppsøving og en mer tradisjonell idrettstilnærming. Begge tilnærmingene var basert på læreplanen i kroppsøving, men innholdet skulle være forskjellig. Forfatterne finner i sine analyser at selv om det var forskjeller på elever som valgte seg til de to ulike tilbudene, var det ingen forskjeller mellom gruppene på de psykologiske målingene som ble gjennomført før og etter intervensionen. I sin diskusjon argumenterer forfatterne for at det å gi elevene et enkelt valg mellom (tilsynelatende) to ulike former for interessetilnærminger i faget ser ut til å være for enkelt. De antyder at det skal mer til for å endre undervisningspraksisen i faget på en måte som støtter forskjellige elevers grunnleggende psykologiske behov.

De fem artiklene i dette temanummeret viser noe av bredden i fagfeltet kroppsøving og idrettsfag. Vi vil takke artikkelforfatterne for deres bidrag. I tillegg vil vi rette en stor takk til de 14 fagfellene som har vurdert artiklene, både de som er trykt her og de som dessverre ble avvist. Forskningsbidragene og fagfellevurderingene er uvurderlige bidrag til å bevege forskningsfeltet vårt!

God lesing!

Øyvind F. Standal \& Kjersti Mordal Moen 